\section{Transhumanism: A Secularist Re-Enchantment of the World?}

\author{
Report from the International Research \\ Symposium "Imagining the (Post-) \\ Human Future: Meaning, Critique and \\ Consequences"
}

Karlsruhe, Germany, July 8-9, 2013

\section{by Franc Mali, University of Ljubljana, Slovenia, Christopher Coenen, ITAS, Hannah Weinhardt, University of Heidelberg, Germany}

In July 2013, an international research symposium in Karlsruhe brought together scholars, mainly from Europe and the US, with a view to stimulating discussions about certain far-reaching visions of the future against the background of current and historical changes in the relationships between science, technology, philosophy and religion. A highly interdisciplinary event which focused on the transhumanist imagination, the symposium not only aimed to shed new light on current discourse about human enhancement and the future of human nature but also to use the topic of transhumanism as a mirror for reflecting on such broader issues as the relationship between science and faith and the role of visions of the future in current processes of innovation.

It came as a surprise to many when Jürgen Habermas began a couple of years ago to display considerable interest in the contemporary role of religion. Reflecting on the prospects of postmetaphysical thinking, he has since scrutinised challenges with which the latter is confronted in a "postsecular" world society. In turn, his reflections have inspired the development of an analytical framework in a research project on "The Transhumanist Imagination: Innovation, Secularization, and Eschatology", in which Hava Tirosh-Samuelson from Arizona State University (ASU), one of the project's principal investigators, is continuing her important earlier work on transhumanism. ${ }^{1}$ The Karlsruhe symposium, organised in cooperation with ASU by the Institute for Technology Assessment and System Analysis (ITAS) of the Karlsruhe Institute of Technology (KIT), was staged as part of this project. ${ }^{2}$ By contextualising the topics of transhumanism and so-called "human enhancement" in discourse on the postsecular and by also raising more general questions about the role of visions of the future in science, technology and innovation, the symposium and the project as a whole can be seen as attempts to further a convergence of research and discussions in such diverse fields as science and technology studies (STS), philosophy, religious studies, theology, technology assessment (TA), cultural studies and sociology. The questions to be discussed during the symposium were also correspondingly diverse: what are the consequences for human society when technology is understood as a privileged site of human agency or is even deemed an exclusive path to individual salvation? To what extent can a historical, philosophical or other scholarly analysis of the transhumanist imagination contribute to our understanding of the interrelations of modern science, technology and religion, including the notions of the "secular" and the "post-secular"? How is techno-scientific imagination linked to the social and economic transformations of late capitalism in the age of globalisation? What forms of authority and credibility underlie and shape imaginations of the posthuman future? What place does imagination of technological futures have in the repertoire of meaning available to public reasoning? And what promises and challenges do dominant imaginations of techno-scientific futures hold and pose for the work of democracy and the institutions of the liberal state? The symposium aimed to bring together scholars not only with diverse disciplinary backgrounds but also with very different and even conflicting stances towards these questions and to stimulate open and constructive discussions among them. ${ }^{3}$

\section{Posthumanism and Current Transhumanism}

The specific topic of the symposium, namely transhumanism and the posthumanist imagination, lent additional diversity and complexity to the deliberations, in particular concerning the notion of "posthumanism". As a worldview and sociocultural movement, transhumanism hopes that science and technology will enable humanity to transcend its limitations, such as death, ageing and disease, as well as its physical and 
cognitive constraints; it tends to see itself as the rightful successor to classical humanism and the Enlightenment. There is, however, an interesting overlap between the lively discussions about transhumanism, which largely take place within broader discourse on "human enhancement", and a similarly heated debate about posthumanism. This overlap might very well have been caused by a terminological ambiguity: while "posthumanism" is often used as a synonym for "transhumanism" (or as a term which refers to a future in which advanced human enhancement technologies or the creation of highly superior artificial intelligence mean that the civilisational successors to humanity are truly posthuman rather than merely transhuman), it can also mean "after humanism". From such a "posthumanist" perspective, certain basic assumptions held by classical humanists, Enlightenment philosophers and modern thinkers (e.g. regarding individual autonomy, human nature or the relationship between humans and technologies) appear either to be obsolete or to have been illusions right from the start: we have never been modern and have always been posthuman. In this sense, the term "posthumanism" is an important element of broad postmodernist discourse and is influential in such fields as STS and cultural studies. In this same regard, the symposium brought together a highly diverse group of scholars, again in order to facilitate an open and fruitful exchange between academics from different epistemic communities and schools of thought.

The first symposium session aimed to clarify the notion of posthumanism and to explore current transhumanist intellectual movements and their societal relevance. It was opened by Andy Miah, who argued that the posthuman already exists and that humanity has always been part of the evolutionary continuum, a "work in progress". Miah regards human enhancement technologies (HET) as the means by which to fully realise posthumanism. In his view, the development of HET should be pursued rather than inhibited. Although there is no guarantee that HET will improve our life or societies, they do have great potential to increase autonomous decision-making and can therefore facilitate a far-reaching "shift from chance to choice", a truly modern goal.
Alfred Nordmann criticised research projects that view human beings as objects of design. Arguing that the world eludes design, and that this is even more true of the future, he questioned attempts to view the future as an object of anticipation, including technology assessment. $\mathrm{He}$ also argued that transhumanists like Nick Bostrom display an astounding degree of shamelessness in their visions of the future which, on the other hand, reveal their strong sense of shame regarding the human body. Reference was made many times throughout the symposium to this notion of the "Promethean shame" (Günther Anders) of being born rather than made, a feeling which results from the ever-increasing efficiency of our machines. The interrelations of posthumanism and transhumanism were addressed by Stefan Sorgner, who pointed out that posthumanism is rooted in postmodernist philosophy, cultural and literary theory and aims to overcome dualisms such as that of the body and the mind, while transhumanism is largely naturalistic and rationalist and positions itself within the Enlightenment tradition. In his view, both approaches have advantages and should be merged in a "metahumanism" which combines practical transhumanism with posthumanist reflection. Matthias Kettner pointed out the relevance of "collective day dreaming", the collective utopian and dystopian forms of imagination in such cultural productions as science fiction films. In his view, they are the keys to a better understanding of sociotechnical imaginaries of the future. Elena Simakova focused on the relevance of transhumanism and the posthumanist imagination to discourse at the science-policy interface, reporting on the results of a workshop she co-organised in Exeter ${ }^{4}$. Referring to her own experience at the Singularity University ${ }^{5}$, Laura Cabrera reflected on the role of transhumanist "visioneers" (a term coined by Patrick McCray which refers to visionary engineers, most of them transhumanists) in the current innovation system. In her view, visioneers in fact play an important role by drawing attention to a possible future which, however, they promote as the only desirable one. By reflecting on visioneering, we may better understand how desires and fears shape the politics and economics of technoscience. Discussing socio-economic 
aspects of research and technology development, Simone Bateman emphasised their relevance for the analysis of transhumanist and other visions of the future of science and society.

\section{Historical and Religious Aspects}

The second session explored historical aspects of the posthumanist imagination and its relationship with religion. Elaine Graham discussed the notion of the postsecular with regard to posthumanist imagination. Both terms refer to thinking patterns that move beyond traditional dualisms: on the one hand the posthuman alerts us to the contingency of boundaries by means of which we distinguish between the human and the nonhuman, the technological and the biological and the artificial and the natural. The notion of the postsecular questions the boundary between the profane and the sacred as well as that between science and religion. If both posthumanist and postsecular discourse converge we may develop a richer understanding of what it means to be human. Eve-Marie Engels provided a thorough account and analysis of Charles Darwin's attitudes towards the proto-transhumanist ideas of the eugenicists. She pointed out that Darwin did not support these ideas but constantly emphasised the importance of moral sense and the law of sympathy as being the most valuable traits of humankind. Christopher Coenen drew attention to recent research by Tirosh-Samuelson, Reinhard Heil, Richard Saage and others on early instances of the transhumanist imagination in Great Britain in the late nineteenth and early twentieth centuries, arguing that much of what is envisioned and discussed today in discourse on human enhancement and transhumanism was already around in these decades (e.g. in writings by Winwood Reade, H.G. Wells, J.B.S. Haldane and Desmond Bernal), particularly with regard to the hope for a fundamental transformation of human corporeality ("mechanical man") and the saturation of the universe with (post)human intelligence. Gregg Zachary made reference to the early history of current information and communication technologies (ICT). Referring to Vannevar Bush and ICT pioneers in the US, he showed how the aim of "cognitive enhancement", which is also a major goal of transhumanism, played an important role in the rise of modern ICT. Cornelius Borck interpreted Dadaist works and ideas by Raoul Hausmann and Hannah Höch as being creative articulations of posthumanist imagination, pointing out that in this context such imagination affirmed the human rather than seeking to overcome it. The ability to reflect on the human condition determines what it means to be human. Michael Hauskeller scrutinised the transhumanist imagination concerning sex life, also by referring to the history of ideas about artificial bodies. He discussed certain transhumanist visions of the future of bodily pleasures that correspond to the fascination with "sexbots", and how they relate to the logocentric ideology of transhumanists which aims to overcome the flesh. Thorsten Moos analysed relationships between the posthuman imagination and eschatology. In his view, transhumanism also expresses but does not (yet) reflect on three main eschatological narratives about the future: the future as a time of perfection, the apocalypse and parousia's delay. Taking into account the reflexive richness of the history of religious eschatological thinking could help us deal with transhumanism in a more realistic way.

\section{Technoscience, Progress and Secular Visions of Salvation}

In her well-attended public evening speech, entitled "Perfecting the future: sociotechnical imaginaries and the public good", Sheila Jasanoff discussed imaginaries of the future more broadly. In order to understand future visions and create accountability for them, she argued that collective and institutionally stabilised discourse about the public good needs to be analysed and compared, as do public practices and forms of social life, while at the same time taking global diversity into account. She highlighted the importance of self-reflection and humility within academic discourse concerning technological visions and urged that due consideration be given to cultural differences, for example with regard to different ways of interrelating the secular and the religious or the legacy of Enlightenment and modernist discourse. 
In his talk on the second day, Steve Fuller claimed that transhumanist thinking is deeply embedded within Western intellectual tradition and can be traced back at least to the Renaissance and certainly to the Enlightenment. Rather than following a naturalistic view, transhumanism emphasises consciousness and rationality, reaffirming the privileged position of humans as reflective beings who are able to understand and ultimately influence evolutionary processes. In order to pursue this goal, the governance of new and emerging science and technology should shift from the precautionary principle to a more proactive approach (such as the transhumanist "proactionary principle"). Armin Grunwald argued that advances in HET create new policy challenges which also require a broader concept of TA. Hermeneutical TA addresses four layers of meaning: the content of future visions of different stakeholders, the historical and cultural backgrounds of emerging HET and transhumanism, the actor constellations and power relations, and the reasons for the interest in particular technologies. In his view, transhumanism and the rise of HET are deeply influenced by neoliberalism, which promotes hedonism and consumerism.

Alexandra Grieser pinpointed transhumanist thought within the history of European thought. In her view, the idea that "more science" means "less religion" is polemical and not a valid claim. Rafael Capurro discussed Martin Heidegger's analysis of humanism as an essentialism that lacks complexity, and as one more "ism" that we should mistrust. Similarly to Grunwald, Peter Wehling argued that the transhumanist obsession with the future and the hopes for human enhancement in general are symptoms of neoliberalism's hegemony which is countered by environmentalism, feminism, postcolonialism and other approaches that also offer alternatives to Western modernist assumptions. John Evans dealt with the question of potential public acceptance of transhumanist visions. Since these visions are based on a very strong faith in science, he analysed data regarding this topic from twelve countries. He pointed out that faith in the ability of science to provide meaning is growing rather strongly, with significant differences between religious and non-religious parts of the population. Shai Lavi argued that, in this context, we should distinguish between religion as a cosmology and religion as a tool-kit and intellectual source of various (including secularist) visions of the future. Justus Hartlieb presented a KIT publication entitled "Ist Technik die Zukunft der menschlichen Natur?" "Is technology the future of human nature?"), a compilation of essays in which young scientists and scholars from various countries responded to this question.

\section{Democracy, Innovation and Imagination}

The concluding session of the symposium focused on the interconnection of democracy, innovation and imagination and the relationship between transhumanism and capitalism. Christoph Rehmann-Sutter opened the discussion with a statement about the ethics of wishing. $\mathrm{He}$ regards wishing as an important instance of agency. In the case of transhumanism, the "wishers" are the potential users of HET. It is crucial to analyse the moral shaping and legitimacy of these wishes. Ben Hurlbut argued that making technology is analogous to making legislation (referring to Langdon Winner). Both are downstream undertakings and therefore imaginations of futures are also imaginations of governance. It is important to ask how responsibility for technology development can be organised institutionally. Like Hurlbut, Brice Laurent rejects the dichotomy between visions and the institutional framework: while the "Human Brain Project"6 obviously expresses a clear vision of the future, it is also an example of how European science policy is structured and how ideas of responsible innovation are implemented. Graham warned against essentialising technology and drew attention to the importance of context, arguing for a feminist perspective on transhumanism. Margo Boenig-Liptsin shifted the focus from politics to economics by quoting a slogan she has often heard at Singularity University, "Doing good by doing well", which expresses the belief that one can make profit by solving the world problems. She pointed out that the market is seen here as a realm of autonomy and free choice, while in actual fact it is a form of governance. Many other participants also articulated concerns about the 
interrelations of transhumanism, consumerism and neoliberalism. Zachary deems many technological developments a direct reaction of industry interests and described the famous transhumanist thinker Ray Kurzweil as a "circus act designed to stimulate an appetite for more production". While many agreed on the strong interdependence of the transhumanist imagination and neoliberal thought and practice, Simakova argued that transhumanism is nowhere near the real agendas of corporations. Sorgner pointed to the high degree of political diversity within the transhumanist movement, and Nasser Zakariya argued that the relevance of the transhumanist imagination is not restricted to the church-like transhumanist movement. Fuller's view that transhumanism is a legitimate heir to important strands of Western intellectual history was challenged by Jasanoff, who questioned whether transhumanist imagination should be taken seriously at all at this stage. If its influence grows in the future, there will be a need to focus on questions of cultural difference and power structures. Other problems which are rarely addressed in discourse about transhumanism, such as global poverty and oppression, remain the crucial questions for scholars in fields such as STS and TA.

\section{Concluding Remarks}

The aim of the symposium was to help bring about a better understanding of the connection between beliefs concerning the future of humanity and technological innovation, focusing on transhumanism and the posthumanist imagination. It showed that the latter can indeed be used as a mirror for reflection on a wide range of contemporary problems and historical questions; it remains unclear, however, whether they act as a distorting mirror or in fact help us to gain new and valid insights into the role of visions of the future in innovation processes and in the development of science and technology. In any case, the current renaissance of the transhumanist imagination points to the existence of unresolved questions in the Western history of ideas concerning science, technology, human nature, religion and social progress. If transhumanism is in fact a secularist attempt to re-enchant the world that will continue to gain relevance in public discourse, it may provoke a broader discussion about the hopes and fears attached to new and emerging science and technology, the roots and political effects of these expectations and the best ways to deal with them.

\section{Notes}

1) A list of topical publications by Tirosh-Samuelson and all other symposium participants will be made available online at http://www.itas.kit.edu/english/projects_coen13 postsym.php.

2) The project (http://transhumanistimagination. csrc.asu.edu/) is conducted by ASU's Center for the Study of Religion and Conflict together with several partners, and is led by Hava Tirosh-Samuelson and J. Benjamin Hurlbut. The symposium was scientifically organised and managed by KITITAS (official in charge: Christopher Coenen) and funded in part by a grant from the John Templeton Foundation/Boston University Historical Society's "Religion and Innovation in Human Affairs" (RIHA) programme.

3) As intended, the symposium was characterised by lively plenary discussions. Since not only all the talks and panel discussions but also all the plenary discussions will be documented online at http:// www.itas.kit.edu/english/projects_coen13_postsym.php, this report largely restricts itself only to the talks and panel discussions.

4) http://www.exeter.ac.uk/news/events/details/index.php?event $=843$

5) http://singularityu.org/

6) http://www.humanbrainproject.eu 